\title{
I nteractional justice as a mediator of the relationship between pay for performance and job satisfaction
}

\author{
Azman Ismail, Azizul Hakim Mashkuri, Ahmad Zaidi Sulaiman, Wong Kee Hock \\ National Defence University of Malaysia (Malaysia) \\ azisma08@gmail.com, azizulhm@gmail.com, zaidi@upnm.edu.my, \\ jeekyelene@upnm.edu.my
}

Received July, 2010

Accepted J une, 2011

\section{Abstract}

Purpose: This study was conducted to examine the effect of pay for performance and interactional justice on job satisfaction.

Design/ methodology/ approach: A survey method was used to collect 107 usable questionnaires from employees who work in the US subsidiary manufacturing firm operating in a silicon valley in East Malaysia, Malaysia.

Findings: The outcomes showed two important findings: first, relationship between interactional justice and adequacy of pay significantly correlated with job satisfaction. Second, relationship between interactional justice and participation in pay systems significantly correlated with job satisfaction. Statistically, this result confirms that interactional justice does act as a mediating variable in the pay for performance models of the studied organization.

Originality/ value: Most previous research tested a direct effect of pay for performance on job satisfaction. Unlike such research approach, this study discovers that interactional justice has strengthened the effect of pay for performance on job satisfaction in a compensation system framework.

Keywords: pay for performance, interactional justice, job satisfaction

Jel Codes: L20 


\section{I ntroduction}

Compensation is a broad construct that may be defined from language and organizational perspectives. In terms of language, it is often defined as salary and wage, remuneration, reward and/or pay system. These terms are used interchangeably in organizations, but their meanings suggest to the same thing (Bergmann \& Scarpello, 2002; Milkovich \& Newman, 2010). In an organizational context, compensation is viewed as an important human resource management issue (Ismail \& Zakaria, 2009; Lawler, 2000) that may be defined as an employer designs and administers various types of pay systems for rewarding its employees who work in different and/or similar job groups (Anthony, Perrewe \& Kacmar, 1996; Henderson, 2009; Ismail, Guatleng, Cheekiong, Ibrahim, Ajis \& Dollah, 2009). Traditionally, most employers design compensation system based on internal organizational variables whereby the type, level and/amount of pay are allocated to employees based on job structure. This perspective emphasizes on pays based on tenure, length of service, seniority, and/or membership and service (Anthony et al., 2002; Florin, Hallock \& Webber, 2010; Milkovich \& Newman, 2010). This compensation practice is often related to Taylorist's product where it is seen as suitable for manufacturing-based industries operating in stable and predictable business conditions and focus on organizational tactical objectives as a direction (Anthony et al., 1996; Henderson, 2009; Ismail et al., 2009).

In an era of globalization, many organizations have shifted the paradigms of compensation system from a traditional job based pay to organizational strategy and culture. Under this perspective, compensation system is designed based on external organizational variables whereby the fluctuation of pay types, levels and/amounts are allocated to employees based on merits, knowledge, skills and/or performance (Lawler, 1995; 2000; Ismail \& Zakaria, 2009; Milkovich \& Newman, 2010). Although the rules for distributing pays based on performance and job are different, they may be used as complementary to attract, retain and motivate competent employees to support organizational and human resource management's strategies and goals (Anthony et al., 1996; Lawler, 1995, 2000).

Pay for performance has two major types: pay for group performance (team based pay and gain-sharing) and pay for individual performance (e.g., merit pay, lump sum bonus, promotion based incentives and variable pay) (Henderson, 2009; Milkovich \& Newman, 2010). However these pay systems have different types, they 
use the similar criterion to allocate pays, which is when an employer rewards additional pays to basic pay in order to meet high performers' needs and expectations (Chang \& Hahn, 2006; Lawler, Ledford \& Chang, 1993; Lee, Law \& Bobko, 1999; Wei \& Rowley, 2009). Under this pay system, the rules for distributing rewards, the fluctuations of pay levels and structures are now contingent upon the level of performances, skills, knowledge and/or competency exhibited by the employees and not the nature of their job structure (AmuedoDorantes \& Mach, 2003; Appelbaum \& Mackenzie, 1996; Ismail \& Zakaria, 2009; Lee et al., 1999). If management can properly implement this pay system this will strongly attract, retain and motivate employees to achieve the major objectives of the organizational pay system: efficiency (i.e., improving performance, quality, customers, and labor costs), equity (i.e., fair pay treatment for employees through recognition of employee contributions and employees' needs) and compliance with laws and regulations (Gomez-Mejia \& Balkin, 1992a, 1992b; Milkovich \& Newman, 2010). Hence, it may motivate employees to sustain and increase organizational competitiveness in a global marketplace (Appelbaum \& Mackenzie, 1996; Lawler, 2000).

Recent studies about compensation management based on a direct effects model highlights that the ability of management to properly implement pay for performance may positively affect job satisfaction (Bhakta \& Nagy, 2005; McCausland, Pouliakas \& Theodossiou, 2005). Many scholars like Fay and Thompson (2001), Lee et al. (1999), and Ismail, Hock and Sulaiman (2007) state that pay for performance has two salient features: participation in pay systems and adequacy of pay. According to a high performing human resource practice, participation in pay systems is often seen as an employer who encourages employees in different hierarchical levels and categories to discuss and share information-processing, decision-making, and/or problem-solving activities related to pay systems (Belcher \& Atchison, 1987; Ismail et al., 2007). Most organizations practice two major participation styles: participation in pay design (e.g., start-up stages of pay system) and participation in pay administration (e.g., operation stages of pay system) (Belfield \& Marsden, 2003; Kim, 1996, 1999; Lee et al., 1999). Participation in the design of pay systems refers to employees who are given more opportunity to provide ideas in establishing pay systems to achieve the major goals of its system, stakeholders needs and/or organizational strategy (Gomez-Mejia \& Balkin, 1992a, 1992b; Lawler et al., 1993).

Participation in the administration of pay systems refers to employee participation in both input and output. Participation in input means employees provide 
suggestions to determine the enterprise's goals, resources, and methods. Participation in output means employees are permitted to share the organization's rewards in profitability and/or the achievement of productivity objectives (CoyleShapiro, Morrow, Richardson \& Dunn, 2002; Kim, 1996, 1999). For example, a prosocial organisational behavior literature highlights that making constructive suggestions in pay for performance system (e.g., merit pay and gain-sharing plans) will encourage employees to be honest in making personal contributions, this may lead to improved job satisfaction (Giacobbe-Miller et al., 1998; Lawler, 1995; Mani, 2002).

Many scholars often interpret adequacy of pay from cultural, organizational and individual perspectives. In terms of cultural perspective, an individualistic culture perceives adequacy of pay as equity (e.g., equitable or inequitable pay) whereas a collective culture perceives adequacy of pay as equality, pay for the length of service or seniority and pay for individuals' needs (Giacobbe-Miller, Miller \& Victorov, 1998; Money \& Graham, 1999). In an organization view, adequacy of pay is often defined as the type, level and/or amount of pay which is provided by an employer to its employee who work in different job groups based on the organizational policy and procedures (Anthony, Perrewe \& Kacmar, 1996; Henderson, 2009). From an individual perspective, adequacy of pay is often viewed based on a social comparison theory, which posits that an individual perceives the adequacy of the type, level and/or amount of pay based on a comparison between what he/she receives and what he/she expects. An individual will perceive the type, level and/or amount of pay as adequate if he/she views that the pays are provided equitable with his/her contribution (e.g., ability to perform job, merit, skills and/or performance) (Adams, 1963, 1965; Skarlicki \& Folger, 1997; Sweeney \& McFarlin, 1993).

Surprisingly, a thorough review of such relationships based on an indirect effects model reveals that effect of pay for performance characteristics of job satisfaction is indirectly affected by feelings of interactional justice (Ismail \& Zakaria, 2009; Pettijohn, Pettijohn \& d'Amico, 2001). According to organizational behavior scholars, such as Greenberg (2003), McShane and Von Glinow (2006) and Skarlicki and Folger (1997) define interactional justice as an important aspect of organizational justice theories, which states that an individual is often sensitive to the quality of interpersonal treatment that they receive from their managers during the enactment of organizational procedures. If an individual perceives that decision makers (e.g., manager or supervisor) practice fair treatments (e.g., shows respect 
and accountable) in performance appraisal systems, this will invoke employees' feelings of interactional justice.

Within a compensation management framework, many scholars think that participation in pay systems, adequacy of pay, interactional justice and job satisfaction are distinct constructs, but highly interrelated. For example, the ability of managers to use fair treatments in determining the type, level and/or amount of pay based on performance ratings and appreciating employees' constructive suggestions in pay for performance plans will strongly invoke employees' feelings of interactional justice. As a result, it may lead to an increased job satisfaction (Bies, Shapiro \& Cummings, 1988; Greenberg, 1996, 2003; Tang \& Sarsfield-Baldwin, 1996; Skarlicki \& Folger, 1997). Although the nature of this relationship has been studied, little is known about the mediating role of interactional justice in pay for performance literature (Ismail \& Nurzawani, 2009; Pettijohn et al., 2001). Many scholars reveal that interactional justice is less emphasized because previous studies have over emphasized on a segmented approach and the direct-effect model in analyzing pay for performance and job satisfaction relationships, as well as given less attention on the significance of interactional justice feelings in developing pay for performance models. Consequently, findings from these studies have not captured the views of employees' feelings of interactional justice in explaining the effectiveness of pay for performance models in dynamic organizations (Hundley \& Runde, 2008; Ismail \& Zakaria, 2000, Money \& Graham, 1999; Pettijohn et al, 2001). Therefore, it motivates the researchers to explore the issue.

This study has four major objectives: first, to measure the relationship between participation in pay systems and job satisfaction. Second, to measure the relationship between adequacy of pay and job satisfaction. Third, to measure the mediating effect of interactional justice in the relationship between participation in pay systems and job satisfaction. Fourth, to measure the mediating effect of interactional justice in the relationship between adequacy of pay and job satisfaction.

\section{Hypotheses}

Theoretical and empirical evidences have been employed to support two types of relationships: 1) relationship between pay for performance and job satisfaction; and 2) relationship between pay for performance, interactional justice and job satisfaction. 


\section{Relationship between pay for performance and job satisfaction}

Previous studies used a direct effects model to examine the type of pay system using different samples, such as 1200 employees from twenty six department (Katzell, Thompson \& Guzzo, 1992), 118 MBA voluntary students from a Midwestern university (Bhakta \& Nagy, 2005), and 9,831 different individuals in United Kingdom (McCausland, Pouliakas \& Theodossiou, 2005). These studies found that the ability of managers to properly design and administer pay for performance plans (i.e., participation in pay systems and adequacy of pay) had increased job satisfaction in the organizations (Bhakta \& Nagy, 2005; Katzell, Thompson \& Guzzo, 1992; McCausland, Pouliakas \& Theodossiou, 2005). Therefore, it can be hypothesized that:

$\mathrm{H} 1$ : There is a positive relationship between participation in pay systems and job satisfaction

$\mathrm{H} 2$ : There is a positive relationship between adequacy of pay and job satisfaction

\section{Relationship between participation in pay systems, interactional justice and job satisfaction}

Further studies about pay administration were implemented using different samples, such as 115 sales people (Pettijohn, Pettijohn \& d'Amico, 2001), 2466 employees (Bradley, Petrescu \& Simmons, 2004), and 132 employees in Malaysian GIATMARA centers (Ismail \& Zakaria, 2009). Findings from these studies reported that the willingness of managers to allow employee participation in making decisions about pay rates and levels (e.g., open discussion, better explanations, and opportunity to bargain) had increased employees' feelings of interactional justice. Consequently, it could lead to an increased job satisfaction in the organizations (Bradley, Petrescu \& Simmons, 2004; Ismail \& Zakaria, 2009; Pettijohn, Pettijohn \& d'Amico, 2001).

\section{Relationship between adequacy of pay, interactional justice and job satisfaction}

Recent studies used an indirect effects model to investigate pay differentials and found that effect of pay for performance on job satisfaction is indirectly affected by interactional justice. For example, recent studies about pay distribution were conducted using different samples, such as employees of 150 mid-Atlantic insurance companies (Schappe, 1998), U.S. group (153 sales representatives and 146 sales managers) and Japanese group (175 of sales representatives and 93 
sales managers) (Money \& Graham, 1999), 132 employees in Malaysian GIATMARA centers (Ismail \& Zakaria, 2009). Outcomes of this study showed that the ability of managers to appropriately provide the levels of pay based on merit had increased employees' feelings of interactional justice about the pay systems. As a result, it could lead to an enhanced job satisfaction in the organizations (Ismail \& Zakaria, 2009; Money \& Graham, 1999; Schapped, 1998).

The empirical studies are consistent with the notion of interactional justice theories, namely Adams' (1963, 1965) equity theory, Leventhal's (1976) self-interest model, Lind and Tyler's (1988) group value model, and Folger, Konovsky and Cropanzano's (1992) due-process appraisal system. For example, Adams' $(1963,1965)$ equity theory explicitly posits that when employees perceive the interaction between output and input ratio as equitable this may lead to increased positive employee outcomes. Conversely, when employees perceive the interaction between output and input ratio is not equitable this may cause negative employee outcomes (Adams', 1963, 1965; Allen \& White, 2002; Sweeney \& McFarlin, 1993). Besides that, Leventhal's (1976) self-interest model suggest six justice rules in making decisions: decisions based on accurate information, apply consistent allocation procedures, do correct decisions, suppress bias, practice moral and ethical standards in decision-making and ensure allocation process meet recipients' expectation and needs.

Moreover, Lind and Tyler's (1988) group value model suggest three types of relational judgments about authorities: standing or status recognition (e.g., assessments of politeness, treatment with dignity, and respect individuals' rights and entitlements), neutrality (e.g., decision-making procedures are unbiased, honest and decision based on evidence), and trust (e.g., motives of the decisionmaker are fair and reasonable or otherwise). Further, Folger et al. (1992) dueprocess appraisal system suggest three justice characteristics; adequate notice (e.g., explanation, discussion and feedback about performance criteria), fair hearing (e.g., informing performance assessments and their procedures through a formal review session) and judgment based on evidence (e.g., applying consistent performance criteria and honesty and fairness principles, as well as providing better explanations about performance ratings and reward allocations). If these justice decisions are properly done by managers, this may determine the adequacy of pays and respect employees' views in the process of distributing the type, level and/or amount of pay based on performance ratings. These practices will strongly invoke employees' feelings of interactional justice, where this may lead to higher job satisfaction (Money \& Graham, 1999; Pettijohn et al., 2001). 
The literature has been used as foundation to develop a conceptual framework for this study as shown in Figure 1.

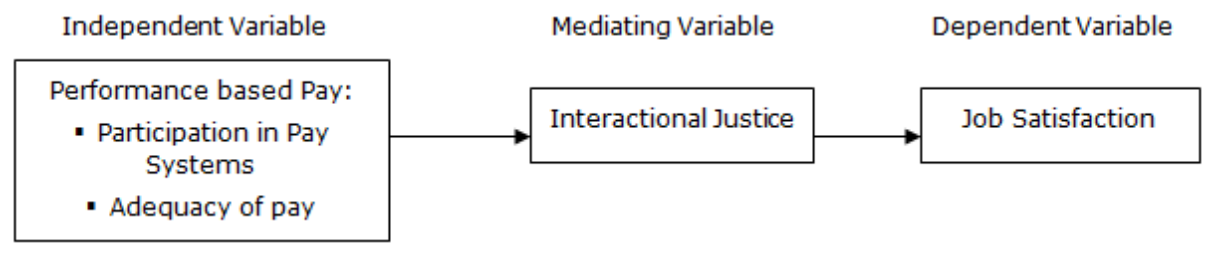

Figure 1: Conceptual Framework

Based on the framework, it can be hypothesized that:

H3: Interactional justice positively mediates the effect of participation in pay systems on job satisfaction

$\mathrm{H} 4$ : Interactional justice positively mediates the effect of adequacy of pay on job satisfaction

\section{Methodology}

\section{Research design}

This study used a cross-sectional research design that allowed the researchers to integrate compensation management literature, the in-depth interview, the pilot study and the actual survey as a main procedure to gather data. Using such methods may gather accurate data, decrease bias and increase quality of data being collected. The use of such methods may gather accurate and less biased data (Cresswell, 1998; Sekaran, 2003). The US subsidiary manufacturing firm is established and operated its business in a free trade zone in East Malaysia, Malaysia. At initial stage, this firm was established to focus on customized semiconductor packaging and hard disk drives. Currently, it almost dominates the electronic export and the largest airfreight exporter in Malaysia. In order to sustain and support the organizational competitiveness, a pay for performance system has been implemented to cope with dynamic organizational changes.

At the initial stage of data collection, the in-depth interviews were conducted involving seven supporting staff and HR executives who have working experiences more than ten years in the organizations. They are selected based on purposive sampling where they have good knowledge and experiences in compensation management. The information gathered from the interviews shows that the organization's compensation and benefits packages have been designed by USA 
consultants to attract, retain and motivate employees to support the organization's strategy and goals. Performance based pay has been implemented at all levels in the organization. In this pay system, performance appraisal, achieving the job targets set up by supervisors and cost saving have been used to assess employee performance. Based on these assessments, high performers will be provided additional rewards in terms of merit increment, discretionary bonus and spot bonus.

The main features of this pay system are pay adequacy and pay participation. In terms of adequacy of pay, percentages of merit increment and discretionary bonus are given based on different performance levels. An average merit increment from basic salary for non-executive employees is four percent. Meanwhile, an average merit increment from basic salary for executives is eight percent. With respect to pay participation, employees' views are sought to suggest the various types of pay (e.g., spot bonus, incentive program and pay preferences) while attending meetings organized by the management of this organization. Majority employees perceive that the ability of HR managers to properly determine the type, level and/or amount of pay according to performance, and appreciate employee participation in the process of allocating pay systems have increased employees' perceptions of procedural justice. Consequently, it may lead to increased job satisfaction. Even though the nature of this relationship is interesting, little empirical research is done in this country (Ismail \& Zakaria, 2009).

Information gathered from the interviews was transcribed, categorized and compared with the relevant pay for performance literature. Next, the triangulated outcomes were used as a guideline to develop the content of the survey questionnaire for a pilot study. Thus, a pilot study was done by discussing the importance, relevance, clarity and suitability of questionnaires with 30 employees. Their opinions were sought to verify the content and format of survey questionnaires for an actual study. Back translation techniques were used to translate the survey questionnaires into English and Malay languages in order to increase the validity and reliability of research findings (Cresswell, 1998; Sekaran, 2000)

\section{Measures}

The survey questionnaire used in this study had 4 sections. Firstly, participation in pay systems was measured using 5 items that were adapted from pay administration literature (Greenberg, 2003; Milkovich \& Newman, 2010; Pettijohn, et al., 2001). Secondly, adequacy of pay was measured using 5 items that were 
adapted from pay distribution literature (Gomez-Mejia \& Balkin, 1992a, 1992b; Kim, 1996, 1999; Milkovich \& Newman, 2007). Thirdly, interactional justice was measured using 8 items that were modified from organizational justice literature (Adams, 1963, 1965; Allen \& White, 2002; Cohen-Charash \& Spector, 2001; Greenberg, 2003; Money \& Graham, 1999; Pettijohn et al., 2001; Skarlicki \& Folger, 1997). Finally, job satisfaction was measured using 8 items that were modified from job satisfaction literature (Oldham, Hackman \& Stepina, 1978; Warr, Cook \& Wall, 1979). All items used in the questionnaires were measured using a 7item scale ranging from "strongly disagree/dissatisfied" (1) to "strongly agree/satisfied" (7). Demographic variables were used as controlling variables because this study focused on employee attitudes.

\section{Unit of analysis and sampling}

Participants in this study consisted of employees of the US subsidiary manufacturing firm operating in a free trade zone in East Malaysia, Malaysia. The researchers had obtained an official approval to conduct the study from the head of the target organization and also received advice from him about the procedures of conducting the survey in his organization. Next, the survey questionnaires were randomly distributed to 250 employees in the organization. Of the total number, 132 usable questionnaires were returned to the researchers, yielding 52.8 percent of the response rate. The number of this sample exceeds the minimum sample of 30 participants as required by probability sampling technique, showing that it may be analyzed using inferential statistics (Sekaran, 2003).

\section{Data analysis}

A Statistical Package for Social Science (SPSS) version 16.0 was used to analyze the data. Firstly, exploratory factor analysis was used to assess the validity and reliability of measurement scales (Hair et al., 1998). Secondly, Pearson correlation analysis and descriptive statistics were conducted to determine the collinear problem, further confirm the validity and reliability of constructs (Tabachnick et al., 2001; Yaacob, 2008). Finally, multiple regression analysis was recommended to assess the magnitude and direction of each independent variable, and vary the mediating variable in the relationship between many independent variables and one dependent variable (Foster, Stine \& Waterman, 1998). Baron and Kenny (1986) suggest that to test mediating effect in the hypothesized model, the researcher should estimate the three following regression equations: firstly, regressing the mediating variable on the dependent variable. Secondly, regressing the dependent 
variable on the independent variable. Thirdly, regressing the dependent variable on both the independent variable and on the mediating variable.

Based on this procedure, a mediating variable can be easily considered when it meets three conditions: first, the independent variable should be significantly correlated with the mediating variable. Second, the independent variable and the mediating variable should also be significantly correlated with the dependent variable. Third, the mediating variable should be significantly correlated with the dependent variable. If this condition is properly implemented, a previously significant effect of independent variable should be reduced to non-significance or reduced in terms of effect size after the inclusion of mediator variable into the analysis (Wong, Hui \& Law, 1995). In this regression analysis, standardized coefficients (standardized beta) were used for all analyses (Jaccard, Turrisi \& Wan, 1990).

\section{Results}

\section{Respondents' characteristics}

Table 1 shows that majority respondents were males (75\%), ages between 21 to 29 years old $(74.8 \%)$, diploma holders $(30.8 \%)$, working experiences less than one year (15\%), and monthly salary between RM1000 to 2000 (54.2\%).

\begin{tabular}{|c|c|c|c|c|c|}
\hline \multicolumn{2}{|c|}{ Gender (\%) } & \multicolumn{2}{|l|}{ Education (\%) } & \multicolumn{2}{|c|}{ Salary* (\%) } \\
\hline Male & 75 & Degree & 9.3 & $<$ RM1000 year & 35.5 \\
\hline \multirow[t]{4}{*}{ Female } & 32 & Diploma & 30.8 & RM1000 - 2000 & 54.2 \\
\hline & & Higher School Certificate & 11.2 & RM2001 - 3000 & 10.3 \\
\hline & & Malaysia Certificate of Education & 35.5 & $>$ RM3000 & 5.6 \\
\hline & & Others & 13.1 & & \\
\hline \multicolumn{2}{|c|}{ Age (\%) } & \multicolumn{2}{|l|}{ Length of Service (\%) } & \multicolumn{2}{|c|}{ * RM=Malaysian Ringgit } \\
\hline$<20$ years & 5.6 & $<1$ year & 15.0 & & \\
\hline 21 - 29 years & 74.8 & $2-5$ years & 5.3 & & \\
\hline 30 - 39 years & 17.8 & $11-15$ years & 1.9 & & \\
\hline$>40$ years & 10.6 & $>16$ year & 4.7 & & \\
\hline
\end{tabular}

Table 1: Respondents' characteristics $(\mathrm{N}=107)$

\section{Validity and reliability analysis}

Table 2 and Table 3 show the results of validity and reliability of the measurement scales. A factor analysis with direct oblimin rotation was done for four variables with 21 items. Next, the Kaiser-Mayer-Olkin Test (KMO) which is a measure of sampling adequacy was conducted for each variable and the results indicated that it was acceptable. Relying on Hair et al., (2006) and Nunally and Bernstein's (1994) guideline, these statistical analyses showed that (1) all research variables exceeded 
the acceptable standard of Kaiser-Meyer-Olkin's value of 0.6 , (2) all research variables were significant in Bartlett's test of sphericity, (3) all research variables had eigenvalues larger than $1,(4)$ the items for each research variable exceeded factor loadings of 0.40 (Hair, Anderson, Tatham \& Black, 1998), and (5) all research variables exceeded the acceptable standard of reliability analysis of 0.70 (Nunally \& Bernstein, 1994). These statistical results showed that the measurement scales used in this study met the acceptable standard of validity and reliability analyses as shown in Table 2 and Table 3.

\begin{tabular}{|c|c|c|c|c|c|}
\hline \multirow{2}{*}{ Variable } & \multirow{2}{*}{ I tem } & \multicolumn{4}{|c|}{ Component } \\
\hline & & 1 & 2 & 3 & 4 \\
\hline $\begin{array}{l}\text { Participation } \\
\text { in } \\
\text { Pay Systems }\end{array}$ & $\begin{array}{l}\text { 1. I am given the opportunity to voice out my opinion on } \\
\text { the design of pay for performancesystem } \\
\text { 2. My supervisor obtains my opinion before making any } \\
\text { change for the pay for performancesystem. } \\
\text { 3. I am given the opportunity to make suggestion in the } \\
\text { process of determining reward allocation. }\end{array}$ & & & $\begin{array}{l}.81 \\
.85 \\
.92\end{array}$ & \\
\hline $\begin{array}{c}\text { Adequacy of } \\
\text { Pay }\end{array}$ & $\begin{array}{l}\text { 1. I receive merit increment or bonus when I have } \\
\text { achieved the target set by supervisor. } \\
\text { 2. The amount of reward is relative with my contribution. } \\
\text { 3. I receive bonus when I have achieve the target set by } \\
\text { supervisor. }\end{array}$ & & & & $\begin{array}{l}.71 \\
.69 \\
.71\end{array}$ \\
\hline $\begin{array}{l}\text { Interactional } \\
\text { J ustice }\end{array}$ & $\begin{array}{l}\text { 1. My supervisor has fairly rewarded me when I consider } \\
\text { the responsibilities I have. } \\
\text { 2.My supervisor has fairly rewarded me when I take into } \\
\text { account the performance rating I achieve. } \\
\text { 3.My supervisor has fairly rewarded me when I consider } \\
\text { the amount of effort that I have put forth. } \\
\text { 4.My supervisor has fairly rewarded me when I consider } \\
\text { the contribution of my job. } \\
\text { 5.My supervisor has fairly rewarded me when I consider } \\
\text { the work that I have done well. } \\
\text { 6.My supervisor makes sure that all employee concerns are } \\
\text { heard before reward decisions are made. } \\
\text { 7.To make reward decisions, my supervisor collects } \\
\text { accurate and complete information from us. } \\
\text { 8.My supervisor clarifies reward decisions and provides } \\
\text { additional information when requested by employees. }\end{array}$ & $\begin{array}{l}.69 \\
.91 \\
.91 \\
.68 \\
.84 \\
.61 \\
.60 \\
.66\end{array}$ & & & \\
\hline $\begin{array}{c}\text { Job } \\
\text { Satisfaction }\end{array}$ & $\begin{array}{l}\text { 1. The amount of pay and fringe benefits I receive. } \\
\text { 2.The recognition you get for good work. } \\
\text { 3.The people I talk to and work with on my job. } \\
\text { 4.The physical working conditions. } \\
\text { 5.The way your organisation is managed. } \\
\text { 6.The amount of responsibility you are given } \\
\text { 7.Your job security }\end{array}$ & & $\begin{array}{l}.80 \\
.70 \\
.74 \\
.82 \\
.77 \\
.73 \\
.81\end{array}$ & & \\
\hline
\end{tabular}

Table 2: Variables, measurement items and components of factor analysis

\begin{tabular}{|c|c|c|c|r|r|r|r|}
\hline Variable & Item & $\begin{array}{c}\text { Factor } \\
\text { Loadings }\end{array}$ & KMO & $\begin{array}{c}\text { Bartlett's Test } \\
\text { of Sphericity }\end{array}$ & Eigenvalue & $\begin{array}{c}\text { Variance } \\
\text { Explained }\end{array}$ & $\begin{array}{c}\text { Cronbach's } \\
\text { Alpha }\end{array}$ \\
\hline $\begin{array}{c}\text { Participation } \\
\text { in Pay } \\
\text { Systems }\end{array}$ & 3 & .81 to .92 & .74 & 155.74 & 2.38 & 79.41 & .87 \\
\hline $\begin{array}{c}\text { Adequacy of } \\
\text { Pay }\end{array}$ & 3 & .69 to .71 & .71 & 181.09 & 2.43 & 81.09 & .88 \\
\hline $\begin{array}{c}\text { Interactional } \\
\text { justice }\end{array}$ & 8 & .60 to .91 & .91 & 741.15 & 5.65 & 70.67 & .94 \\
\hline $\begin{array}{c}\text { Job } \\
\text { satisfaction }\end{array}$ & 7 & .70 to .82 & .87 & 470.91 & 4.64 & 66.21 & .91 \\
\hline
\end{tabular}

Table 3: Factor loadings and reliability coefficients of the instruments 


\section{Analysis of the constructs}

Table 4 shows the results of Pearson correlation analysis and descriptive statistics. The means for all variables are from 3.0 to 3.2, signifying that the level of participation in pay systems, adequacy of pay, interactional justice, and job satisfaction are ranging from moderately high (3.0) to highest level (7). The correlation coefficients for the relationship between the independent variable (i.e., participation in pay systems and adequacy of pay) and the mediating variable (i.e., interactional justice), and the relationship between the dependent variable (i.e., job satisfaction) were less than 0.90 , indicating the data were not affected by serious collinearity problem (Hair et al., 1998). Thus, these statistical results provide further evidence of validity and reliability for measurement scales used in this research (Hair et al., 1998; Nunally \& Bernstein, 1994).

\begin{tabular}{|c|r|r|r|r|r|r|}
\hline \multirow{2}{*}{ Variables } & \multirow{2}{*}{ Mean } & $\begin{array}{c}\text { Standard } \\
\text { Deviation }\end{array}$ & \multicolumn{3}{|c|}{ Pearson Correlation (r) } \\
\cline { 5 - 8 } & & 1 & $\mathbf{1}$ & $\mathbf{3}$ & $\mathbf{4}$ \\
\hline $\begin{array}{c}\text { 1. Participation in Pay } \\
\text { Systems }\end{array}$ & 3.3 & 1.72 & 1 & & & \\
\hline 2. Adequacy of Pay & 4.3 & 1.68 & $.54^{* *}$ & 1 & & \\
\hline $\begin{array}{c}\text { 3. Interactional } \\
\text { Justice }\end{array}$ & 4.0 & 1.46 & $.62^{* *}$ & $.70^{* *}$ & 1 & \\
\hline 4. Job Satisfaction & 4.2 & 1.58 & $.51^{* *}$ & $.57^{* *}$ & $.66^{* *}$ & 1 \\
\hline
\end{tabular}

Table 4: Descriptive statistics and Pearson correlation analysis

\section{Results of testing hypothesis 1 and hypothesis 2}

As described in Table 4, the results of Pearson correlation analysis showed two important findings: first, participation in pay systems significantly correlated with job satisfaction $(r=51, p<0.01$ ), therefore $\mathrm{H} 1$ was supported. Second, adequacy of pay significantly correlated with job satisfaction $(r=57, p<0.01)$, therefore $\mathrm{H} 2$ was supported. Statistically, these results demonstrate that participation in pay systems and adequacy of pay have been important determinants of job satisfaction in the studied organization.

\section{Results of testing hypothesis 3 and 4}

Table 5, Table 6 and Table 7 show the outcomes of multiple regression analysis that were conducted based on mediating model testing procedure as advocated by Baron and Kenny (1986). Relying on this procedure, the mediating effect of interactional justice in the hypothesized model exists when it meets three conditions: firstly, the independent variable must affect mediating variable in the first equation. Table 5 shows that pay for performance (i.e., participation in pay 
systems and adequacy of pay) significantly correlated with interactional justice ( $\beta=.35, p<0.001 ; \beta=.51, p<0.001$ ), signifying that this relationship met the first mediating model testing requirement.

\begin{tabular}{|c|c|}
\hline Independent Variable & $\begin{array}{c}\text { Mediating Variable } \\
\text { (I nteractional J ustice) }\end{array}$ \\
\hline $\begin{array}{c}\text { Participation in Pay systems } \\
\text { Adequacy of Pay }\end{array}$ & $.35 * * *$ \\
R Square & $.51 * * *$ \\
\hline Adjusted R Square & .57 \\
R Square Change & .56 \\
F & .57 \\
F D R Square & $68.42 * * *$ \\
Note: Significance at $* \mathrm{p}<0.05 ; * * \mathrm{p}<0.01 ; * * * \mathrm{p}<0.001$ \\
\hline
\end{tabular}

Table 5: The results of multiple regression showing the relationship between pay for performance and interactional justice

\begin{tabular}{|c|c|}
\hline Independent Variable & $\begin{array}{l}\text { Dependent Variable } \\
\text { (Job Satisfaction) }\end{array}$ \\
\hline $\begin{array}{c}\text { Participation in Pay systems } \\
\text { Adequacy of Pay }\end{array}$ & $\begin{array}{l}.28 * * \\
.42 * * * \\
\end{array}$ \\
\hline $\begin{array}{c}\text { R Square } \\
\text { Adjusted R Square } \\
\text { R Square Change } \\
\text { F } \\
\text { F } \Delta \text { R Square }\end{array}$ & $\begin{array}{c}.38 \\
.40 \\
.38 \\
31.96^{* * *} \\
31.96^{* * *}\end{array}$ \\
\hline
\end{tabular}

Table 6: The results of multiple regression showing the relationship between pay for performance and job satisfaction

Finally, the mediating variable must affect the dependent variable in the third equation. At the initial stage, an examination of collinearity in Table 7 shows that the tolerance value for the relationships: between participation in pay systems and job satisfaction was .59, between adequacy of pay and job satisfaction was .50, and between interactional justice and job satisfaction was .43. This tolerance value was more than tolerance value of .20 (as a rule of thumb), indicating the variables were not affected by multicollinearity problem (Fox, 1991; Tabachnick \& Fidell, 2001).

Thus, Table 7 shows that relationship between interactional justice and pay for performance (i.e., participation in pay systems and adequacy of pay) positively and significantly correlated with job satisfaction ( $\beta=.46, p<0.001$ ), therefore $\mathrm{H} 3$ and $\mathrm{H} 4$ were fully supported. This result is consistent with Baron and Kenny's (1986) mediating model testing condition where the effect of pay for performance on job satisfaction was decreased when interactional justice included in the analysis. Further, it indicates that interactional justice acts as an important mediating variable in the relationship between pay for performance and job satisfaction. 


\begin{tabular}{|c|c|}
\hline \multirow{2}{*}{ Variables } & $\begin{array}{c}\text { Dependent Variable } \\
\text { (Job Satisfaction) }\end{array}$ \\
\cline { 2 - 2 } Step 1 \\
\hline Participation in Pay Systems & .12 \\
Adequacy of Pay & .19 \\
I nteractional J ustice & $.46 * * *$ \\
\hline R Square & 47 \\
Adjusted R Square & .46 \\
R Square Change & .47 \\
F & $30.48 * * *$ \\
F $\Delta$ R Square & $30.48 * * *$ \\
\hline Note: Significance at $* \mathrm{p}<0.05 ; * * \mathrm{p}<0.01 ; * * * \mathrm{p}<0.001$ \\
\hline
\end{tabular}

Table 7: The results of multiple regression showing the relationship between pay for performance, interactional justice and job satisfaction

\section{Discussion and implications}

The findings of this study confirm that interactional justice does act as a full mediating variable in the relationship between pay for performance and job satisfaction in the pay system models of studied organization. In the organizational context, managers use compensation policy and rules set up by the stakeholder to determine the type, level and/or amount of pay for high performers. Employees perceive that their managers encourage employees who work in different job groups to participate in the design and administration of pay systems and able to allocate sufficient rewards based on employee performance. When employees perceive that they receive adequate pays from their employers and they are actively involved in the pay systems, this has increased employees' feelings of interactional justice. As a result, it may lead to higher job satisfaction in the studied organization.

The implications of this study can be divided into three categories: theoretical contribution, robustness of research methodology, and practical contribution. In terms of theoretical contribution, the findings of this study highlight two major issues: firstly, relationship between participation in pay systems and interactional has been an important predictor of job satisfaction. This result is consistent with studies by Bradley, Petrescu and Simmons (2004), Pettijohn, Pettijohn and d'Amico (2001), and Ismail and Zakaria (2009). Secondly, relationship between adequacy of pay and interactional justice has been an important predictor of job satisfaction. This result is consistent with studies by Schapped (1998), Money and Graham (1999), and Ismail and Zakaria (2009). In overall, this study has provided a great potential to understand the influence of feelings of interactional justice in the pay for performance models of the studied organizations, as well as to support and extend previous research conducted in most Western countries. 
With respect to the robustness of research methodology, the data gathered from the survey questionnaire have exceeded a minimum standard of validity and reliability analyses; this can lead to the production of accurate findings. In terms of practical contributions, the findings of this study may be used to upgrade the efficiency of designing and administering pay for performance in organizations. The improvement efforts can be done in two major aspects: firstly, the extra rewards for high performers can be perceived more valuable if the type, level and/or amount of pay are revised according to current national cost of living and organizational changes. This may help them to give more focus on achieving organizational goals because they view that extra rewards fulfill their expectations, standards of living and statuses in society. Secondly, the content and method of management development programs need to emphasize on creative soft skills (e.g., stimulate employees' intellectuals in doing job, respect employees' voices, counsel employees to increase their potentials to achieve better career, learn new problem solving skills approach and share the organizational interests) may upgrade the ability of managers to practice good interaction styles in managing compensation system. If organizations heavily consider such suggestions, this will decrease employees' misconceptions and misjudgments, as well as increase their appreciations and understanding about the implementation of performance based pay. This perception can motivate positive subsequent attitudinal and behavioral outcomes (e.g., satisfaction, commitment, performance and positive work ethics), which in turn, lead to sustain and maintain organizational competitiveness in a global economy.

\section{Limitations and directions for future research}

The conclusion drawn from the results of this study should consider the following limitations. Firstly, the data was only taken once during the duration of this study. Therefore, it did not capture the developmental issues such as intra-individual change and restrictions of making inference to participants and/or causal connections between variables of interest. Secondly, this study only examines the relationship between latent variables and the conclusion drawn from this study does not specify the relationship between specific indicators for the independent variable, mediating variable and dependent variable. Thirdly, this study only focused on particular elements of pay for performance and neglected other important factors (e.g., communication, pay distribution criteria and management responsibility). Fourthly, other pay for performance outcomes (e.g., job commitment, job performance, job turnover and deviant behavior) that are significant for organizations and employees are not discussed in this study (Ismail \& Zakaria, 
2009; Milkovich \& Newman, 2010). Fifthly, although a substantial amount of variance in dependent measures explained by the significant predictors is identified, there are still a number of unexplainable factors that can be incorporated to identify the causal relationship among variables and their relative explanatory power (Tabachnick et al., 2001). Finally, the sample for this study was taken using a convenient sampling technique in a private business firm. These limitations may decrease the ability of generalizing the results of this study to other organizational settings.

The conceptual and methodology limitations of this study need to be considered when designing future research. Firstly, the organizational and personal characteristics that act as a potential variable and can influence the effectiveness of pay for performance should be further explored. If organizational and personal characteristics are used in research, this may provide meaningful perspectives for understanding the individual differences and similarities that affect attitudinal and behavioral outcomes. Secondly, the weaknesses of cross sectional research design may be overcome if longitudinal studies are used to collect data and describe the patterns of change and the direction and magnitude of causal relationships between variables of interest. Thirdly, the findings of this study may produce different results if this study is done in more than one organization. Fourthly, as an extension of the interactional justice, other theoretical constructs of organizational justice theory (e.g., distributive justice and procedural justice) needs to be considered because they have been widely recognized as an important link between pay for performance and employee outcomes (Bradley, Petrescu \& Simmons, 2004; Ismail \& Zakaria, 2009; McCausland, Pouliakas, \& Theodossiou, 2005; Pettijohn, Pettijohn \& d'Amico, 2001). The importance of these issues needs to be further discussed in future studies.

\section{Conclusion}

This study used a conceptual framework that was developed based on the pay for performance research literature. The measurement scales used in this study satisfactorily met the standards of validity and reliability analyses. Outcomes of multiple regression analysis confirmed that interactional justice fully mediated the effect of pay for performance (i.e., participation in pay systems and adequacy of pay) on job satisfaction in the studied organizations. This result has also supported pay for performance literature mostly published in Western countries. Therefore, current research and practice within the pay system model needs to consider perceptions of interactional justice as a critical aspect of the pay systems. This 
study further suggests that HR managers and/or managers should be trained to practice consistently good treatments while allocating rewards and involving employees in making reward decisions. The ability of HR managers and/or managers to practice such treatments will strongly invoke employees' feelings of interactional justice, which in turn lead to increased positive attitudinal and behavioral outcomes. Thus, such positive outcomes may help to maintain and support organizational strategy and goals.

\section{References}

ADAMS, J.S. (1965). Inequity in social exchange. In L. Berkowitz (Eds.), Advances in Experimental Social Psychology, 2: 267-299.

ADAMS, J.S. (1963). Towards an understanding of inequity. Journal of Abnormal and Social Psychology, 67: 422-436. http://dx.doi.org/10.1037/h0040968

ALLEN, R.S.; WHITE, C.S. (2002). Equity sensitivity theory: A test of responses of two types of under-reward situations. Journal of Managerial Issues, 14(4): 435152.

AMUEDO-DORANTES, C.; MACH, T. (2003). Performance pay and fringe benefits. Work incentives or compensating wage differentials? International Journal of Manpower, 24(6): 673-698. http://dx.doi.org/10.1108/01437720310496157

ANTHONY, W.P., PERREWE, P.L.; KACMAR, K.M. (1996). Strategic human resource management. Fort Worth, TX: The Dryden Press.

ANTHONY, W.P., PERREWE, P.L., \& KACMAR, K.M. (2002). Strategic human resource management. New York: Harcourt Brace \& Company.

APPELBAUM, S.H.; MACKENZIE, L. (1996). Compensation in the year 2000: Pay for performance. Health Manpower Management, 22(3): 31-39. http://dx.doi.org/10.1108/ $\underline{09552069610125919}$

BARON, R. M.; KENNY, D. A. (1986). The moderator-mediator variable distinction in social psychological research: Conceptual, strategic, and statistical considerations. Journal of Personality and Social Psychology, 51: 1173-1182. http://dx.doi.org/ 10.1037/0022-3514.51.6.1173

BELCHER, D.W.; ATCHISON, T. (1987). Compensation administration. Englewood Cliffs, NJ: Prentice Hall. 
BELFIELD, R.; MARSDEN, D. (2003). Performance pay, monitoring environments, and establishment performance. International Journal of Manpower, 24(4): 452 471. http://dx.doi.org/10.1108/01437720310485933

BERGMANN, T.J.; SCARPELLO, V.G. (2002). Compensation decision making. United States: South-Western Thomson Learning.

BHAKTA, M. \& NAGY, MARK S. (2005), Are Higher Pay Increases Necessarily Better? Applied H.R.M. Research, 10(1), 1-12.

BIES, R.J.; SHARPIRO, D.L.; CUMMINGS, L.L. (1988). Causal accounts and managing organizational conflict: is it enough to say it's not my fault? Communication Research, 15: 381-399. http://dx.doi.org/10.1177/009365088015004003

BRADLEY, S.; PETRESCU, A.I. \& SIMMONS, R. (2004) 'The impacts of human resource management practices and pay inequality on workers' job satisfaction', Working Paper, Lancaster University, Lancaster. Available at: http://www. lums. lancs. ac.uk/publications/viewpdf/000276/

CHANG, E.; HAHN, J. (2006). Does pay-for-performance enhance perceived distributive justice for collectivistics employees? Personnel Review, 35(4): 397412. http://dx.doi.org/10.1108/00483480610670571

COHEN-CHARASH, Y.; SPECTOR, P.E. (2001). The role of justice in organization: A meta-analysis. Organizational Behavior and Human Decision Processes, 86: 278324. http://dx.doi.org/10.1006/obhd.2001.2958

COYLE-SHAPIRO, J.A-M.; MORROW, P.C.; RICHARDSON, R.; DUNN, S.R. (2002). Using profit sharing to enhance employee attitudes: A longitudinal examination of the effects on trust and commitment. Human Resource Management, 41(4): 423 439. http://dx.doi.org/10.1002/hrm.10052

CRESSWELL, J.W. (1998). Qualitative inquiry and research design: Choosing among five traditions. London: SAGE publications.

FOLGER, R.; KONOVSKY, M.A.; CROPANZANO, R. (1992). A due process metaphor for performance appraisal. Research in Organizational Behavior, 3: 129-177.

FOSTER, D.P.; STINE, B.; WATERMAN, R. (1998). Business analysis using regression: A casebook. US: Springer-Verlag. 
FLORIN, B.; HALLOCK, K.F.; WEBBER, D. (2010). Executive pay and pay for performance: Methodological considerations and future directions. In Martocchio, J., Liao, H., \& Joshi, A. (eds). Research in Personnels and Human Resource Management, 29: 49-86.

FOX, J. (1991). Regression diagnostics. Thousand Oaks, CA: Sage Publications.

GIACOBBE-MILLER, J.K.; MILLER, D.J.; VICTOROV, V.I. (1998). A comparison of Russian and U.S. pay allocation decisions, distributive justice judgements, and productivity under different payment conditions. Personnel Psychology, 51(1): 137-364. http://dx.doi.org/10.1111/j.1744-6570.1998.tb00719.x

GIATMARA Malaysia. (2008). Sepintas lalu sejarah GIATMARA. http://www. giatmara.edu.my/BM/objektif/objektif.htm, 2008-September $15^{\text {th }}$.

GOMEZ-MEJIA, L.R.; BALKIN, D.B. (1992a). Compensation, organizational strategy, and firm performance. Cincinnati, $\mathrm{OH}$ : South Western Publishing Co.

GOMEZ-MEJIA, L.R.; BALKIN, D.B. (1992b). The determinants of faculty pay: An agency theory perspective. Academy of Management Journal, 35(5): 921-955. http://dx.doi.org/10.2307/256535

GREENBERG, J. (2003). Creating unfairness by mandating fair procedures: The hidden words of a pay-for-performance plan. Human Resource Management Review, 13: 41-57. http://dx.doi.org/10.1016/S1053-4822(02)00098-0

GREENBERG, J. (1996). The quest for justice on the job: Essays and experiments. Thousand Oaks, CA: Sage.

HAIR, J.F.; ANDERSON, R.E.; TATHAM, R.L.; BLACK, W.C. (2006). Multivariate data analysis. New Jersey: Prentice Hall International, Inc.

HENDERSON, R.I. (2009). Compensation management in a knowledge based-world. New Jersey: Prentice-Hall.

HUNDLEY, G.; RUNDE, C.S. (2008). Cross-national differences in determination of pay fairness judgments. Do the cultural differences play a role? In Devinney, T, Pedersen, T., \& Tihanyi, C. (eds). The global diffusion of human resource practices: Institutional and Cultural Limits. Advances in International Management, 21: 191-210. 
ISMAIL, A.; HOCK, W.K.; SULAIMAN, S. (2007). Relationship between Pay for Performance Features and Job Satisfaction: Does Interactional Justice Act As a Mediating Role? The seventh AAM International Conference, 2, 495-503, May 2224, 2007, Science University of Malaysia, Penang, Malaysia.

ISMAIL, A.; ZAKARIA, N. (2009). Relationship between Interactional Justice and Pay for Performance as an Antecedent of J ob Satisfaction: an Empirical Study in Malaysia, International J ournal of Business and Management, 4(3): 190-199.

ISMAIL, A.; GUATLENG, O.; CHEEKIONG, T.; IBRAHIM, Z.; AJIS, M.N.; DOLLAH, N.F. (2009). The indirect effect of distributive justice in the relationship between pay structure and work attitudes and behavior. European Journal of Social Sciences, 11(2): 234-248.

JACCARD, J.; TURRISI, R.; WAN, C.K (1990). Interaction Effects in Multiple Regression, (pp. 72). Newsbury Park, California: SAGE Publications, Inc.

KATZELL, R.A.; THOMPSON, D.E.; GUZZO, R.A. (1992). “How job satisfaction and job performance are not linked". In Job Satisfaction: How People Feel About Their Jobs and How It Affects Their Performance, Edited by: Cranny, C. J., Cain Smith, P. and Stone, E. F. 195-217. New York, NY: Lexington Books.

KIM, D.O. (1999). Determinants of the survival of gain sharing programs. Industrial and Labor Relations Review, 53(1): 21-38. http://dx.doi.org/10.2307/2696160

KIM, D.O. (1996). Factors influencing organizational performance in gain sharing programs. Industrial Relations, 35(2): 227-44. http://dx.doi.org/10.1111/j.1468232X.1996.tb00404.x

LAWLER, E.D. (2000). Rewarding Excellence: Pay Strategies for the New Economy. California: Jossey-Bass.

LAWLER, E.E. (1995). Choosing an involvement strategy. Academy of Management Executive, 2: 197-203. http://dx.doi.org/10.5465/AME.1988.4277254

LAWLER, E.E.; LEDFORD, G.; CHANG, L. (1993). Who uses skill-based pay, and why. Compensation and Benefits Review, March-April: 22-26. http://dx.doi.org/ 10.1177/088636879302500204

LEE, C.; LAW, K.S.; \& BOBKO, P. (1999). The importance of justice perceptions on pay effectiveness: A two-year study of a skill-based pay plan. Journal of Management, 25(6): 851-873. http://dx.doi.org/10.1177/014920639902500604 
LEVENTHAL, G.S. (1976). Fairness in social relationships. In Spence, J.T., and Carson, R.C. Contemporary Topics in Social Psychology. Morristown, New Jersey: General Learning Press. 211-240.

LIND, E.A.; TYLER, T.R. (1988). The social psychology of procedural justice. New York: Plenum.

MANI, B.G. (2002). Performance appraisal systems, productivity, and motivation: A case study. Public Personnel Management, 31(2): 141-160.

MCCAUSLAND, W.D.; POULIAKAS, K.; THEODOSSIOU, I. (2005). Some are punished and some are rewarded. A study of the impact of performance pay on job satisfaction. International Journal of Manpower, 26(7/8): 636-659. http://dx.doi.org/10.1108/01437720510628112

MCSHANE, S.L.; VON GLINOW, M.A. (2006). Organizational Behavior. Irwin: McGraw-Hill.

MILKOVICH, G.T.; NEWMAN, J.M. (2010). Compensation. New York: McGraw Hill.

MONEY, R.B.; GRAHAM, J.L. (1999). Salesperson performance, pay and job satisfaction: Test of a model using data collected in the United States and Japan. Journal of International Business Studies, 30: 149-172. http://dx.doi.org/ 10.1057/palgrave.jibs.8490064

NUNALLY, J.C.; BERNSTEIN, I.H. (1994). Psychometric theory. New York: McGrawHill.

OLDHAM, G.R.; HACKMAN, J.R.; STEPINA, L.P. (1978). Norms for the job diagnostic survey (Technical Report No. 16). New Heaven: CT: Yale University.

PETTIJOHN, C.E.; PETTIJOHN, L.S.; D'AMICO, M. (2001). Charateristics of performance appraisals and their impact on sales force satisfaction. Human Resource Development Quarterly, 12(2): 127-146. http://dx.doi.org/10.1002/hrdq.4

SCHAPPE, S.P. (1998). The influence of job satisfaction, organizational commitment, and fairness perceptions on organizational citizenship behavior. The Journal of Psychology, 132(3), 277-290. http://dx.doi.org/10.1080/00223989809599167

SEKARAN, U. (2003). Research methods for business: A skill building approach. New York: John Wiley \& Sons, Inc. 
SKARLICKI, D.P.; FOLGER, R. (1997). Retaliation in the workplace: The roles of distributive, procedural and interactional justice. Journal of Applied Psychology, 82: 434- 443. http://dx.doi.org/10.1037/0021-9010.82.3.434

SWEENEY, P.D.; McFARLIN, D.B. (1993). Workers' evaluation of the "ends" and the "means": An examination of four models of distributive and procedural justice. Organizational Behavior and Human Decision Processes, 55: 23-49. http://dx.doi.org/10.1006/ obhd.1993.1022

TABACHNICK, B.G.; FIDELL, L.S. (2001). Using multivariate statistics. Sydney: Allyn \& Bacon.

TANG, T.L.P.; SARSFIELD-BALDWIN, L.J . (1996). Distributive and procedural justice as related to satisfaction and commitment. S.A.M. Advanced Management Journal, 61(3): 25-32.

WARR, P.B., COOK, J.; WALL, T.D. (1979). Scales for the measurement of some work attitudes and aspects of psychological well-being. Journal of Occupational Psychology, 52: 129-148.

WEI, Q.; ROWLEY, C. (2009). Pay for performance in China's non-public sector enterprises. Asia-Pacific Journal of Business Administration, 1(2): 119-143. http://dx.doi.org/10.1108/17574320910989087

WONG, C.; HUI, C.; LAW, K.S. (1995). Causal relationships between attitudinal antecedents to turnover. Academy of Management J ournal, 342-346.

Intangible Capital, 2011 (www.intangiblecapital.org)

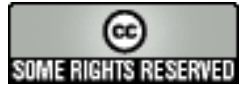

Article's contents are provided on a Attribution-Non Commercial 3.0 Creative commons license. Readers are allowed to copy, distribute and communicate article's contents, provided the author's and Intangible Capital journal's names are included. It must not be used for commercial purposes. To see the complete licence contents, please visit http://creativecommons.org/licenses/by-nc/3.0/es/ 